\section{Europe delays BST decision}

\section{Munich}

Negotiations now under way in the European Communities (EC) over licensing the genetically engineered cow hormone bovine somatotropin (BST) could set the tone for years to come for the introduction of biotechnology products in the European market. Researchers, pharmaceutical companies, farmers and consumers are watching closely for an indication of whether BST will eventually be licensed in Europe.

Despite, or perhaps because of, the intense scrutiny, EC Agriculture Commissioner Ray MacSharry did not last week propose an 18-month moratorium on BST, as he was widely expected to do, in order to allow for further scientific study. Such a proposal could emerge from a meeting in September of the EC council of ministers.

BST, also known as bovine growth hormone, is a peptide hormone of 191 amino acids that is also found naturally in cows. Injected once or twice monthly, the hormone can increase milk production in cows from 15 to 30 per cent above normal. Monsanto, Eli Lilly and other US pharmaceuticals manufacturers have invested large amounts into producing BST by genetic-engineering techniques, although the recombinant hormone has yet to be licensed in the United States and Europe. It would be the first genetically engineered product to be licensed in Europe for agricultural markets.

The BST issue has attracted attention because of the many interest groups affected. The differing views of consumers, environmentalists, farmers, industrialists, and United States and European politicians have created a thorny tangle from which EC bureaucrats are struggling to escape.

Field tests on BST have caused controversy since 1987 in West Germany, where environmentalists manned the barricades against the idea of a hormone-injected "turbo-cow". They objected to BST on the grounds that it might have harmful effects on milk and meat consumers or on the cows themselves. Most studies so far indicate no harmful effects on either people or cows, admitted consumer rights advocate Thomas Schlier in Bonn, but the long-term risks have yet to be determined.

Anti-BST sentiment in West Germany and other EC countries has shifted to economic arguments, according to Schlier. BST opponents ask why Europe should approve a substance that would only increase dairy surpluses and might put small farmers out of business. For example, the rank and file of UK farmers oppose its introduction, which they see as a threat to their jobs.

Pressure from the United States may have contributed to the EC Commission decision not to request a moratorium in the licensing of BST. In a sharply worded letter that was not made public, US Agriculture Secretary Clayton Yuetter reminded EC of its pledge to liberalize agriculture trade made in the "Uruguay round" of international trade negotiations. In a 1986 "high-tech directive", EC promised to accelerate and reduce the cost of the introduction of biotechnologyderived products in Europe.

Yuetter wrote that a BST ban, or even a moratorium, would be seen as a non-tariff barrier to trade, and therefore subject to US trade sanctions.

Monsanto sees more menace in the issue. Gerhard Schwämmlein, a Monsanto executive based in Brussels, said that the

\section{London}

THE government of the Byelorussian SSR last week announced contingency plans to evacuate up to 103,000 inhabitants of land seriously polluted by the Chernobyl disaster. The decision followed the publication of a new set of maps (the third this year), showing even more islands of elevated radioactivity in southern and PACIFIC HIGHWAY

\section{Loan for Brazil}

\section{São Paulo}

THE Brazilian government has announced that the Inter-American Development Bank (IADB) has resumed loans to finance the completion of the highway that will connect Brazil to ports on Peru's Pacific coast. But the loan is dependent on the government undertaking environmental protection measures in the Amazon, including the creation of two new protected areas in the states of Acre and Amazonas, the demarcation of the limits of areas reserved for native peoples and increased satellite surveillance of the forest.

The bank suspended loans in 1987 because of fears that the project might cause the same environmental problems in Acre that were created in Rondonia when clearing of the forests led to colonization. Thousands of migrants barely subsist on the infertile soils.

Construction of the 504-kilometre highway began 30 years ago with the aim of facilitating exports from the Amazon area to Asia via the Pacific ocean. Two hundred kilometres have yet to be paved.

The government has also accepted a loan of $\$ 8$ million from the World Bank to monitor forest burning.

Ricardo Bonalume Neto "next trade war" between the United States and the EC "could be in the offing" over BST, especially if the United States licenses BST while Europe bans it. Schwämmlein says a moratorium makes "little difference either way", as a BST "technical review" could not be completed before November 1990. But the apparent EC reversal on the marketing of biotechnology products is "depressing" enough, he said, to make the international pharmaceutical industry, and other hightechnology industries, consider pulling research and development out of Europe.

Despite the harsh words, all sides seem eager to avoid repeating the mistakes of the last US-EC 'hormone war'. EC refusal to accept beef treated with steroid hormones such as testosterone led earlier this year to US sanctions, still in place, of up to $\$ 100$ million on a variety of European industries.

Steven Dickman

\title{
Continuing plans for evacuation
}

eastern Byelorussia. Although claims by members of the Byelorussian opposition (see Nature 340, 258; 27 July 1989) that the fallout-bearing cloud was 'seeded' over Byelorussia to protect Moscow have been denied by Dr Yurii Izrael, head of the Soviet meteorological service, there is no doubt that radiation in Byelorussia is causing increasing concern to the authorities. Repeated demands for personal dosimeters for the inhabitants of the affected area (which amounts to approximately 20 per cent of the agricultural land of the republic) have now, in theory, been satisfied.

The Academy of Sciences of the Byelorussian SSR this summer held a contest for an appropriate instrument, and production of the winning design has now been authorized, although the output by the end of the year is unlikely to be more than 300 .

In the meantime, grass-roots anger at what is seen as Moscow's neglect of the situation continues to grow. According to Cyrvonaja Zmiens, the newspaper of the Byelorussian Komsomol (Young Communist League), local doctors consider that the official 'safe limit' of 35 rems for a nominal 70-year life-span is too high. Students from the Byelorussian State University, who were sent to harvest potatoes in polluted areas, were hastily withdrawn after pressure from their parents, a move that evoked even further protests from local inhabitants whose children have to remain in such areas all the year round. And when these children have been sent for a few weeks to a 'Young Pioneers' camp outside the contaminated zone, Cyrvonaja Zmiens notes, they have been subjected to psychological trauma by children from 'clean' areas who refuse to have any contact with them.

Vera Rich 